\title{
THE SYSTEMIC IMPORTANCE OF THE CONSTITUTIONAL ESTABLISHMENT OF THE CAPITAL IN THE MEMBER STATES OF THE EUROPEAN UNION ${ }^{1}$
}

\author{
A IMPORTÂNCIA SISTÊMICA DAS INSTITUIÇÕES CONSTITUCIONAIS \\ DA CAPITAL NOS ESTADOS-MEMBROS DA UNIÃO EUROPEIA
}

Radosław Grabowski

\begin{abstract}
The Constitution of the Republic of Poland of 1997 guarantees the capital function of Warsaw in art. 29. This provision is part of a set of regulations determining the so called state symbols, i.e. the emblem, flag, and anthem. While the recognition of state symbols at the constitutional level does not raise objections, such regulation does not seem to be necessary as regards the capital of the state. The question arises whether such practice exists in other contemporary institutions, or whether the Polish case is isolated.

Keywords: Constitutional establishment. European Union. Poland.

\section{Resumo}

A Constituição da República da Polônia de 1997 garante que a capital seja Warsóvia em seu art. 29. Esta regra é parte de uma série de normas que determinam os chamados símbolos do Estado, isto é, o brasão, a bandeira e o hino. Enquanto o reconhecimento de símbolos de Estado em nível constitucional não levanta objeções, esta regulamentação parece não ser necessária no que diz respeito à capital do Estado. Surge a questão se tais práticas existem em outras instituições contemporâneas ou se o caso polonês é isolado.
\end{abstract}

Palavras-chave: Instituições constitucionais. União Europeia. Polônia.

Sumário: 1. Constitutional regulations indicating the capital of the state. 2. Constitutional regulations to determine the capital of the state. 3. Lack of constitutional regulation of social functions. 4. Conclusions. 5. References.

The Constitution of the Republic of Poland of 1997 (Dz.U. 1997, Nr 78, poz. 483) guarantees the capital function of Warsaw in art. 29. This provision is part of a set of regulations determining the so called state symbols, i.e. the emblem, flag, and

Artigo submetido em 05/10/2017, pareceres de análise em 04/12/2017, 10/12/2017 e 12/12/2017, aprovação comunicada em 15/12/2017.

2 The author is an Associate Professor in Institute of Political Science on the Faculty of Sociology and History of University of Rzeszow in Poland. E-mail: <chatazawsia@wp.pl>. 
anthem. While the recognition of state symbols at the constitutional level does not raise objections, such regulation does not seem to be necessary as regards the capital of the state. The question arises whether such practice exists in other contemporary institutions, or whether the Polish case is isolated.

The answer to this question requires a representative group of states to make credible decisions. This analysis covers all EU Member States. Although this group is heterogeneous, in the context of the conducted researchthis fact should be regarded as an advantage, not a drawback. Among the countries that are part of the European Union in carrying out research for the purposes of this text, i.e. at the turn of 2016 and 2017, we can point old democracies, states of the former Eastern bloc, Nordic states with their constitutional characteristics, monarchies and republics, states operating on the basis of constitutions enacted in the $21^{\text {st }}, 20^{\text {th }}$ and $19^{\text {th }}$ centuries and not even having a constitution in the material sense.

This diversity will determine whether there is widespread practice in the EU countries for the preservation of capital functions at the constitutional level, as well as whether it is a dominant model or other possible solutions. As far as diversity in this area is concerned, it is necessary to determine what the causes are. This will allow us to conclude in what cases the constitutional protection of the capital functions of a particular centre is unnecessary, and whether such cases allow to draw conclusions that may apply in Polish political practice.

In some cases, matters related to the capital of the state will be compiled with regulations concerning state or national symbols. The impression is that these things are often treated in the constitutions together, and the procedure will determine the intentions of the legislators, show editorial inconsistencies or deficiencies in the regulations being analyzed.

\section{CONSTITUTIONAL REGULATIONS INDICATING THE CAPITAL OF THE STATE}

The Federal Constitutional Law of the Republic of Austria (STAŚKIEWICZ, 2011 , p. 21) makes a comprehensive regulation, not only indicating that the capital of the federation and the seat of its supreme authorities is Vienna (art. $5 \mathrm{sec}$. 1), but also introducing solutions applicable to emergencies. In such a case, at the request of the Federal Government, the Federal President may transfer the seat of the bodies 
mentioned in sec. 1 to another place in the federation territory (art. $5 \mathrm{sec}$. 2). Such a solution is likely to guarantee state activity independently of the circumstances, including the event of inability to perform functions assigned to particular supreme bodies at their usual headquarters.

The provisions of the Constitution of the Kingdom of Belgium (STAŚKIEWICZ, 2011, p. 85) are less developed. Article 194 of the Constitution establishes the city of Brussels as the capital of Belgium and indicates that it is the seat of the Federal Government. Such provisions do not apply to the place of operation of the authorities in emergency situations, but this does not appear to be a significant shortcoming; on the contrary, flexibility in this respect should be seen as an advantage. The only restriction in the Belgian Constitution on the performance of central government functions is the inability to initiate work on constitutional change or continuation of the constitution, unless parliamentary assemblies can gatherin the territory of the state (art. 196).

The Constitution of the Republic of Bulgaria of 1991 (STAŚKIEWICZ, 2011, p. 113) introduced very laconic regulations relating to the capital of the state. The provisions of article 169 state that the capital of the Republic of Bulgaria is the city of Sofia. The conciseness of this regulation contrasts with the detailed information referring to the emblem or flag of the republic, which is the content of art. 164 and art. 166.

In accordance with art. 13 of the Constitution of the Republic of Croatia of 1990 (WÓJCIK; PETRYŃSKA, 2007), Zagreb is the capital of the republic. At the same time, the Constitution also requires the issuance of a law that defines the status, scope of action, and the constitution of the capital city.

The Constitution of the Czech Republic of 1992 (STAŚKIEWICZ, 2011, p. 191) determines in art. 13 that the capital of the republic is Prague. As in the case of Bulgaria, the Czech Constitution devotes far more space to state symbols (art. 14).

The situation is similar in Spain. Art. 4 of the Spanish Constitution of 1978 (STAŚKIEWICZ, 2011, p. 341) precisely describes the matters related to the Spanish flag and the flags of autonomous communities, while the content of art. 5 is extremely laconic: "The capital of the state is Madrid."

The matter of the capital in the Dutch Constitution of 1814 has been treated marginally (STAŚKIEWICZ, 2011, p. 375). Art. 32 clearly states that the capital city is 
Amsterdam, but it happens "by the way". The content of this regulation is as follows: "As soon as possible after taking power by the King, the King is solemnly pledged and paid homage at a public and joint meeting of the Estates General in the capital city of Amsterdam. The king swears or promises fidelity to the Constitution and worthy holding of his office; the rules are set by the law ".

The Constitution of the Republic of Lithuania of 1992 (STAŚKIEWICZ, 2011, p. 419) sets the city of Vilnius the capital of the Republic of Lithuania in art. 17. The capital functions of Vilnus were further emphasized in art. 82 of the Constitution, which orders the newly elected President of the Republic to take an oath "in Vilnius, in the presence of representatives of the Seimasmembers".

The constitutional regulations of the Grand Duchy of Luxembourg (STAŚKIEWICZ, 2011, p. 443), determined the capital of state - Luxembourg - in art. 109. It is also the seat of government, which can be changed, but only temporarily, and for important reasons. The content of art. 109 explains the enigmatic wording of art. 71 of the Constitution, according to which the sessions of the Chamber of Deputies "take place at the location where the administration of the Grand Duchy is based." As a clarification, it should be mentioned that there are 107,000 inhabitants in Luxembourg out of 567 thousand inhabitants of the Grand Duchy, which guarantees its capital positionas not threatened (UNDATA, [2017]).

The Basic Law of the Federal Republic of Germany of 1949(STAŚKIEWICZ, 2011, p. 519) in art. 22 sec. 1 points to Berlin as the capital of Germany. It also specifies that the task of the Federation is to represent the entire state in the capital, whereas the details are governed by a federal law. It should be recalled that art. 22 was supplemented by the above regulations by the Act of 2006. During the existence of two German states, that was in 1949-1990, the Basic Law of the Federal Republic of Germany did not address the matter of the capital. Berlin has functioned as the capital of united Germany since 1990, although the Federal President has been in office since 1994, the Bundestag since 1999, and the Bundesrat since 2000. Until the year 2006, art.22 only governed the pattern of the national flag ("The Federation Flag is black-red-gold"), these provisions are now contained in art. 22 sec. 2.

The 1997 Constitution of the Republic of Poland regulates the matter of the capital of the state, but it does so in a laconic manner: "Art. 29. The capital of the Republic of Poland is Warsaw". The conciseness of the above provisions does not 
seem to be accidental, as matters concerning national symbols have also been briefly defined in art. 28.

The Romanian Constitution (STAŚKIEWICZ, 2011, p. 665) clearly states that Bucharest is the capital of Romania (art. 14). Concise provisions concern national symbols similarly: the flag (art. $12 \mathrm{sec} .1$ ), national holidays (art. $12 \mathrm{sec}$. 2), the national anthem (art. 12 sec. 3 ).

The 1992 Constitution of the Slovak Republic (STAŚKIEWICZ, 2011, p. 693) rules in art. 1 that the capital of the Slovak Republic is Bratislava. The constitutional provisions also mandate in sec. 2 to make statutory regulations of the position of Bratislava as the capital of the Slovak Republic. As being original - and potentially leading to the change of the location of central authorities during the emergency - the provisions of art. $10 \mathrm{sec} .3$ state that "the manner of exercising public authority during the state of war, martial law, exceptional state shall be determined by the constitutional law".

According to art. 10 of the Constitution of the Republic of Slovenia of 1991 (STAŚKIEWICZ, 2011, p. 725), the capital of the state is Ljubljana. The conciseness of this provision contrasts with the volume of art. 6 , regulating state symbols. As an example, it is worth quoting: "The symbol of Slovenia is a shield, in the middle of which the blue background is depicted on the top of the Triglav mountain in white; Below are two wavy blue lines depicting sea and river; Above is an inverted triangle made up of three golden six-pointed stars. The shield is surrounded by a red border. The emblem corresponds to the accepted geometric and colour rules. "

The Basic Law of Hungary (WARSZAWA, 2015) in the article marked with the letter $F$ states that the capital of Hungary is Budapest. As in many other constitutions, attention is drawn to the disproportion between the matters related to capital functions and the excessive attachment of the legislator to the details of state symbols. In the article marked with the letter I sec. 2, we read: "The Hungarian flag consists of three horizontal stripes, equal to the width of the following - looking from above - colours: red, white and green; red symbolizes power, white - fidelity, green hope".

The Constitution of the Italian Republic of 1947 (STAŚKIEWICZ, 2011, p. 845) defines the territorial structure in art. 114 (municipalities, provinces, metropolitan cities, regions, state) as well as the basic assumptions of individual autonomy. In 
sentences 2 and 3, the Constitution states: "Rome is the capital of the Republic. State law governs its constitution. "Equally briefly, the matters related to the flag of the Republic are regulated in art. 12.

\section{CONSTITUTIONAL REGULATIONS TO DETERMINE THE CAPITAL OF THE STATE}

The Irish Constitution of July 11937 (STAŚKIEWICZ, 2011, p. 393) does not address the matter of the capital, but its provisions contain information that allows us to determine the location of the Irish capital. In art. 12, regulating the activities of the President of the Republic, we can findsec. 11 point 1, according to which "the official seat of the President is the city of Dublin or its surroundings". Similar information was found in the article referring to the parliament - art. 15 sec. 1 point 3 states: "The Oireachtas are gathering in or near Dublin or anywhere else that they may choose from time to time." It should therefore be recognized that the capital of Ireland is Dublin City, and there (or in the vicinity) the President resides and the meetings of the two Chambers of the Parliament are held, as a matter of principle.

The Latvian regulations have a similar design. In the contents of the Constitution of the Republic of Latvia in 1922 (STAŚKIEWICZ, 2011, p. 459), there were no regulations concerning the capital of the state nor the "capital" or "capital city". In contrast, art. 15 shows that the meetings of the Saeimaare held in Riga, but only in exceptional circumstances may they take place elsewhere. This allows us to recognize that the Latvian Constitution attributes the functions of a capital to Riga.

None of the constitutional acts that constitute the Swedish constitution is directly related to the matter of the capital of the state, but information on this subject can be found in the Government Form Act - Akty konstytucyjne z lat 1810-1991: Akt o formie Rządu (Regeringsformen), Akt o sukcesji (Successionsordningen), Akt o wolności druku (Tryckfrihetsförordningen), Akt o wolności wypowiedzi (Yttrandefrihetsgrundlagen) - (STAŚKIEWICZ, 2011, p. 749). Chapter $4 \S 1$ states: "The Riksdag shall meet annually at the session. The session is held in Stockholm unless the Riksdag or its Chairman decides otherwise due to the need to ensure the safety or freedom of assembly. "Rigsdag may also meet in a different location than Stockholm, in the event of a war or a war threat "(chapter $15 \S 1)$. As a matter of 
principle, however, the seat of Rigsdagu is Stockholm, which means that the city is typical of the capital.

\section{LACK OF CONSTITUTIONAL REGULATION OF SOCIAL FUNCTIONS}

The provisions of the Constitution of the Republic of Cyprus of 16 August 1960 (WARSZAWA, 2013) use the term "capital of the Republic", indicating the seat of the Constitutional Tribunal (art. $133 \mathrm{sec}$. 2) and the Supreme Court (art. $153 \mathrm{sec} .2$ ) but there is no regulation indicating the capital city.Although art. 173 determines the largest urban centres in the republic (Nicosia, Limasol, Famagusta, Larnaca and Paphos), none of them is attributed to capitalism. Nicosia, the undisputed capital of Cyprus, has been split between South Cyprus which is the seat of the authorities of the Cyprus Republic and North Cyprus, recognized only by Turkey as the capital, since 1964. The idea of neutrality and equal treatment of persons of Greek and Turkish nationality is ubiquitous in the Constitution of the Republic of Cyprus and even forms the practice of using state symbols. According to art. $4 \mathrm{sec}$. 1. "The Republic has its own flag with a neutral pattern and color(...)" Republic authorities, legal persons of public law and public utility organizations hang the flag of the Republic and at the same time the Greek and Turkish flags (art. $4 \mathrm{sec}$. 2) Municipal authorities and institutions, as well as citizens of the Republic and any other organization, have the right to display at their seat the flag of the Republic, the Greek flag or the Turkish flag without limitation (art.4 sec. 3 and 4 ).

The Danish Constitution of 1953 devotes no place to the symbols of the state nor to the capital. The provisions of $\S 37$ of the Danish Constitution relate to matters involving the capital of the country, stating that "Folketing gathers in the place which is the seat of the Government, except in exceptional circumstances in which the Folketing can gather anywhere in the Kingdom" (STAŚKIEWICZ, 2011, p. 213) but they do not indicate a specific location. In practice this is not necessary, since Copenhagen has been the capital of Denmark since 1445. The official Danish state flag also has a $15^{\text {th }}$ century tradition (the so-called Dannebrog) being a model for the flags of all Scandinavian countries, which explains the lack of regulation in this regard in the Constitution of Denmark (ROSKILDE, 2010; COPENHAGEN, 2015).

In the Constitution of Estonia of 1992 (STAŚKIEWICZ, 2011, p. 227) there are no regulations indicating a centre performing the functions of the capital, but it is 
probably due to the specificity of Estonia - there are few urban centres and only one city. In 2011 the three largest ones respectively were: Tallinn 393 thousand people, Tartu 98 thousand people and Narva 58 thousand people and the tenth biggest city (Võru) counted less than 13 thousand residents (STATISTICS ESTONIA, 2012). In such a situation, Tallinn's position as the seat of the most important state institutions is not undermined. The status of the Estonian flag, recognized as a state flag in 1918 and used as a national since the $80^{\prime}$ 's of the $19^{\text {th }}$ (EESTI.PL, 2005) is also not questioned. This explains the lack of constitutional regulation of state symbols.

The Finnish Constitution of June 11, 1999 (STAŚKIEWICZ, 2011, p. 249) does not refer to the question of the seat of the central government, nor does it regulate the matter of state symbols. This fact does not mean that we are dealing with freedom in this regard. On the contrary, there is an attachment to tradition in Finland, and therefore, despite the passing of 205 years, the determination concerning the Finnish capital, dated April 8, 1812, is still in force. At that time, the Russian Emperor Alexander I signed the edict under which Helsinki was the capital of the Grand Duchy of Finland, established in 1809 on the Finnish territory detached from Sweden (KIRBY, 2006, p. 81). So, the current design of the flag of Finland has been officially used since 1918 .

Matters related to the seat of the state authorities, that is, the exercise of the function of the capital, are not subject to the regulation of the Constitution of the

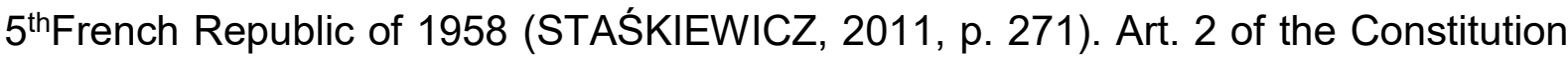
contains provisions on state symbols -i.e. official language, emblem, anthem - but they do not refer to the capital. It seems, however, that in France there is no need. Despite the fact that the list of places performing the functions of the French capital is long -Orleans, Troyes, Versailles, Bordeaux, or Vichy can be listed here but still - the capital position of Paris is not questioned and therefore does not require constitutional guarantees.

The position of Athens, which is the capital of Greece, despite the lack of constitutional foundations, does not seem to be at threat (STAŚKIEWICZ, 2011, p. 297). Athens has been the capital of Greece since 1834, when the Bavarian king Otto Bavarian moved the headquarters to Nafplio. The Royal Palace was built at the time, where the Hellenic Parliament is now located. Athens is the largest city centre in Greece - in 2011 it was inhabited by over 660 thousand people. But the population of the Athens metropolitan area, which consists of 46 municipalities, is over 3 million people. It is worth mentioning that the Constitution of Greece of 1975 not only does 
not indicate the capital of the state, but also in no way refers to its symbols, such as the emblem, flag or anthem. The official Greek flag of distinctive character has been used since the National Uprising of 1821, formally in force between 1822-1828 and 1969-1975, the status thereof as a state symbol was restored in 1978.

The 1964 Constitution of Malta (STAŚKIEWICZ, 2011, p. 471) does not refer to the question of the seat of state authorities, since there is no need for it - out of a total of 420 thousand inhabitants. About half of the inhabitants of Malta live in Valletta (UNDATA, [2017]) and another 100,000 inhabitants in the nearest area. The rest of the island of Malta is the island of Gozo and three other inhabited islands are poorly populated. While the Constitution of Malta does not regulate the matter of the capital, it regulatesthe national symbols: flags and emblems in art. 36.

The Constitution of Portugal of 1976 (STAŚKIEWICZ, 2011, p. 599) also lacks regulations on the capital of the state. The administrative and economic centre of the country is the Lisbon region, which in 2015 was inhabited by 2,884 thousand people (UNDATA, [2017]). In art. 11, the Constitution regulates the matters of the national flag, the national anthem and the official language. It can therefore be assumed that lack of constitutional guarantees onthe status of Lisbon is a result of its strong position as a capital.

None of the laws of the United Kingdom of Great Britain and Northern Ireland (STAŚKIEWICZ, 2011, p. 871) indicate which centre performs the functions of the capital. The answer to the question about the United Kingdom is - due to the history of the British Isles - obvious but not easy due to the complicated territorial legal status of London. The city of London is just part of the administrative region of Greater London, a metropolis inhabited by more than 8 million people. Greater London, which formally is not a city, consists of 33 municipalities, two of which are the City of London and the City of Westminster. An even larger area occupies the London agglomeration, inhabited by 10 million people (GREATER LONDON, 2013). The British constitutional law also does not report on the matter of state symbols, which is understandable, as these govern a centuries-old tradition.

\section{$4 \quad$ CONCLUSIONS}

Among the 28 Member States of the EU, 16 possess constitutional regulations for the capital. These are: Austria, Belgium, Bulgaria, Croatia, Czech 
Republic, Spain, the Netherlands, Lithuania, Luxemburg, Germany, Poland, Romania, Slovakia, Slovenia and Hungary. As far as system traditions are concerned, this group brings together a slightly larger number of EU Member States located in Eastern Europe (9 out of 11) and (7 out of 17) in Western Europe. Thus, in Eastern Europe there is greater attachment to regulating the legal matter being analyzed.

Taking into account that in this group 4 out of 6 are monarchies are members of the EU, 12 out of 20 are republics, it should be recognized that neither the monarchic nor republican type of state determines the relationship of the legislator to the constitutional guarantee of capital functions. It is characteristic that the constitutional norms defining the capital of the country are absent in Nordic countries and those with the pro-nordic sympathies (Estonia and Latvia).

A specific group consists of Ireland, Latvia, Sweden, whose constitutions do not indicate the capital, but designate the seats of Parliament (Ireland, Latvia, Ireland) and the office of the President office (Ireland). These solutions should be considered interesting, but due to the small size of the group, further divisions cannot be carried out.

The third group to be formed is Cyprus, Denmark, Estonia, Finland, France, Greece, Malta, Portugal and the United Kingdom. None of the above countries have established constitutional regulations concerning the capital. Among them there are 5 states (Denmark, Estonia, Finland, Greece, United Kingdom) whose political systems do not regulate the matter of state or national symbols. This group is heterogeneous it consists of 3 countries of Northern Europe, 4 countries of Southern Europe (if we include Portugal) and 2 countries of Western Europe. You can notice here the socalled state democracies, but they are not represented much, because only by the United Kingdom, France and Denmark.

In conclusion, it must be stated that there is a full spectrum of attitudes in the Member States of the European Union relating to the safeguarding of capital functions at the constitutional level. There are many far-reaching differences which makes it difficult to indicate a dominant model. The primary causes of this phenomenon should be seen in the existence of constitutional traditions specific to each of the constitutional systems, secondary in the absence of a uniform standard for the analyzed regulations, but one should not expect it to be worked out. 
It is important to recognize that constitutional regulations establishing a state capital are unnecessary, as long as we are dealing with a long tradition in this field or in case of existence of only one centre able to perform capital functions in the state. At the same time, the constitutional establishment of the capital in Luxembourg, Slovakia or Romania can be indicated, which seems unnecessary.

It seems that in most countries that have protected the capital functions in the constitution, this has been performed "in the name of tradition", indicating the only possible (for various reasons) urban centre. It is clear that there is no particular idea of such regulations and their from the territorial structure of the state, with the exception of the Constitution of the Italian Republic. As a result, in most cases, we are dealing with too restrictive regulations that do not contribute to the constitution as an act of central importance to the state. This also applies to the Constitution of the Republic of Poland, which, while establishing its capital in Warsaw, does nothing further. Such a solution does not perform any function other than consolidating the location of the capital.

\section{REFERENCES}

COPENHAGEN. In: EncyclopædiaBritannica, 2015, https://www.britannica.com/ place/Copenhagen (07.02.2017).

EESTI.PL. Symbole narodowe Estonii. 24 grudnia 2005. http://www.eesti.pl/ symbole-narodowe-estonii-11925.html (07.02.2017).

GREATER LONDON. In: Encyclopædia Britannica, 2013, https://www.britannica. com/place/Greater-London (07.02.2017).

KIRBY, D. A Concise History of Finland. Cambridge University Press, 2006, p. 81. KONSTYTUCJA Republiki Chorwacji. TransI. T. M. Wójcik, M. Petryńska, Warszawa, 2007.

KONSTYTUCJA Rzeczypospolitej Polskiej z dnia 2 kwietnia 1997 r. Dz.U. 1997, Nr 78, poz. 483. http://biblioteka.sejm.gov.pl/konstytucje-swiata-polska/ (02.01.2017).

KONSTYTUCJI Republiki Cypryjskiej z dnia 16 sierpnia 1960 r., tłum. L. Akritidis, P. Akritidis, wstęp P. Osiewicz, Warszawa, 2013.

ROSKILDE. In: EncyclopædiaBritannica, 2010, https://www.britannica.com/ place/Roskilde-Denmark (07.02.2017). 
STAŚKIEWICZ, W. (Ed.). Akty konstytucyjne z lat 1810-1991: Akt o formie Rządu (Regeringsformen), Akt o sukcesji (Successionsordningen), Akt o wolności druku (Tryckfrihetsförordningen), Akt o wolności wypowiedzi (Yttrandefrihetsgrundlagen), transl. K. Dembiński, M. Grzybowski. In: Konstytucje państw Unii Europejskiej. Warszawa, 2011, p. 749.

STAŚKIEWICZ, W. (Ed.). Federalna Ustawa Konstytucyjna Republiki Austrii z dnia 1 października 1920 r. transl. P. Czarny i B. Naleziński. In: Konstytucje państw Unii Europejskiej. Warszawa, 2011, p. 21.

STAŚKIEWICZ, W. (Ed.). Konstytucja Estonii przyjęta przez obywateli Republiki Estońskiej w referendum przeprowadzonym w dniu 28 czerwca 1992 r., transl. A. Puu. In: Konstytucje państw Unii Europejskiej. Warszawa, 2011, p. 227.

STAŚKIEWICZ, W. (Ed.). Konstytucja Grecji z dnia 9 czerwca 1975 r. transl. G. i W. Uliccy, B. Zdaniuk, N. Ciesielczyk. In: Konstytucje państw Unii Europejskiej. Warszawa, 2011, p. 297.

STAŚKIEWICZ, W. (Ed.). Konstytucja Hiszpanii z dnia 27 grudnia 1978 r. transl. T. Mołdawa. In: Konstytucje państw Unii Europejskiej. Warszawa, 2011, p. 341.

STAŚKIEWICZ, W. (Ed.). Konstytucja Irlandii uchwalona przez Naród dnia 1 lipca 1937 r., transl. S. Grabowska. In: Konstytucje państw Unii Europejskiej. Warszawa, 2011, p. 393.

STAŚKIEWICZ, W. (Ed.). Konstytucja Królestwa Belgii z dnia 7 lutego 1831 r. transl. W. Skrzydło. In: Konstytucje państw Unii Europejskiej. Warszawa, 2011, p. 85. STAŚKIEWICZ, W. (Ed.). Konstytucja Królestwa Danii z dnia 5 czerwca 1953 r., transl. M. Grzybowski. In: Konstytucje państw Unii Europejskiej. Warszawa, 2011, p. 213.

STAŚKIEWICZ, W. (Ed.). Konstytucja Królestwa Niderlandów z dnia 28 marca 1814 r. transl. A. Głowacki, B. Szepietowska. In: Konstytucje państw Unii Europejskiej. Warszawa, 2011, p. 375.

STAŚKIEWICZ, W. (Ed.). Konstytucja Malty z dnia 21 września 1964 r., transl. J. Winczorek. In: Konstytucje państw Unii Europejskiej. Warszawa, 2011, p. 471.

STAŚKIEWICZ, W. (Ed.). Konstytucja Republiki Bułgarii Uchwalona przez Wielkie Zgromadzenie Narodowe Bułgarii w dniu 12 lipca 1991 r. transl. H. Karpińska. In: Konstytucje państw Unii Europejskiej. Warszawa, 2011, p. 113. 
STAŚKIEWICZ, W. (Ed.). Konstytucja Republiki Czeskiej z dnia 16 grudnia 1992 r. transl. M. Kruk-Jarosz. In: Konstytucje państw Unii Europejskiej. Warszawa, 2011, p. 191.

STAŚKIEWICZ, W. (Ed.). Konstytucja Republiki Finlandii z dnia 11 czerwca 1999 r., transl. J. Osiński. In: Konstytucje państw Unii Europejskiej. Warszawa, 2011, p. 249.

STAŚKIEWICZ, W. (Ed.). Konstytucja Republiki Francuskiej z dnia 4 października 1958 r. transl. W. Skrzydło. In: Konstytucje państw Unii Europejskiej. Warszawa, 2011, p. 271.

STAŚKIEWICZ, W. (Ed.). Konstytucja Republiki Litewskiej, transl. H. Wisner. In: Konstytucje państw Unii Europejskiej. Warszawa, 2011, p. 419.

STAŚKIEWICZ, W. (Ed.). Konstytucja Republiki Łotewskiej uchwalona przez Zgromadzenie Konstytucyjne w dniu 15 lutego 1922 r. transl. L. Gołubiec, I. Jaroszkiewicz. In: Konstytucje państw Unii Europejskiej. Warszawa, 2011, p. 459. STAŚKIEWICZ, W. (Ed.). Konstytucja Republiki Portugalskiej z dnia 2 kwietnia 1976 r., transl. A. Wojtyczek-Bonnand. In: Konstytucje państw Unii Europejskiej. Warszawa, 2011, p. 599.

STAŚKIEWICZ, W. (Ed.). Konstytucja Republiki Słowackiej z dnia 1 września 1992 r. transl. K. Skotnicki. In: Konstytucje państw Unii Europejskiej. Warszawa, 2011, p. 693.

STAŚKIEWICZ, W. (Ed.). Konstytucja Republiki Słowenii z dnia 23 grudnia 1991 r., transl. P. Winczorek. In: Konstytucje państw Unii Europejskiej. Warszawa, 2011, p. 725.

STAŚKIEWICZ, W. (Ed.). Konstytucja Republiki Włoskiej z dnia 27 grudnia 1947 r., transl. Z. Witkowski. In: Konstytucje państw Unii Europejskiej. Warszawa, 2011, p. 845.

STAŚKIEWICZ, W. (Ed.). Konstytucja Rumunii z dnia 21 listopada 1991 r. transl. A. Cosma. In: Konstytucje państw Unii Europejskiej. Warszawa, 2011, p. 665.

STAŚKIEWICZ, W. (Ed.). Konstytucja Wielkiego Księstwa Luksemburga z dnia 17 października 1868 r. transl. A. Wojtyczek-Bonnad, K. Wojtyczek In: Konstytucje państw Unii Europejskiej. Warszawa, 2011, p. 443. 
STAŚKIEWICZ, W. (Ed.). Ustawa Zasadnicza Republiki Federalnej Niemiec z dnia 23 maja 1949 r. transl. B. Banaszak i A. Malicka. In: Konstytucje państw Unii Europejskiej. Warszawa, 2011, p. 519.

STAŚKIEWICZ, W. (Ed.). Ustawy ustrojowe Zjednoczonego Królestwa Wielkiej Brytanii i Irlandii Północnej, transl. S. Kubas. In: Konstytucje państw Unii Europejskiej. Warszawa, 2011, p. 871.

STATISTICS ESTONIA. PHC 2011: The population of Estonia is concentrated around larger cities. 12 December 2012. http://www.stat.ee/news-release-2012-158 (07.02.2017).

UNDATA - United Nations Statistics Division. Luxembourg. http://data.un. org/CountryProfile.aspx?crName=Luxembourg (07.02.2017).

UNDATA - United Nations Statistics Division. Malta. http://data.un. org/CountryProfile.aspx?crName=Malta (07.02.2017).

UNDATA - United Nations Statistics Division. Portugal. http://data.un. org/CountryProfile.aspx?crname=Portugal (07.02.2017).

USTAWA Zasadnicza Węgier, transl. J. Snopek, Warszawa, 2015. 